\title{
Mempertanyakan Stereotip Kecantikan (Analisis Semiotika tentang Representasi Kecantikan dalam Film Adaptasi Snow White and the Huntsman (2012) dan Mirror Mirror (2012))
}

\author{
Dira Elita \\ Alumnus Program Studi Ilmu Komunikasi, Universitas Islam Indonesia Yogyakarta
}

\begin{abstract}
Fairy tales is a kind of story told orally by our parents from one generation to another. Mainly, the main story is about "beauty":the princess should be beautiful and the prince should be handsome and know how to fight. When fairy tales such as Snow White adapted into movies, issues related to the concept of beauty is not left behind. This is part of main depiction represented within this kind of film that leads to many stereotypes. This research focuses on how stereotypes of beauty are represented in two fairy tales-based adaptation films, Snow White and the Huntsman (2012) and Mirror mirror (2012).

In terms of the methodology, this research employs Roland Barthes's thought, especially his structural semiotic analysis. By applying Barthes's "two orders of signification" (denotation and connotation), the analysis focuses on three thematic elements: body, costume, and characteristic.
\end{abstract}

Keywords: conservatism ideology, fairy tales, myths, structural semiotics analysis.

\begin{abstract}
Abstrak
Dongeng merupakan bentuk cerita yang disampaikan secara lisan oleh orang tua kepada anaknya, dari generasi ke generasi. Tema utama dalam dongeng adalah tentang "kecantikan": seorang putri haruslah cantik dan seorang pangeran harus ganteng dan paham caranya bertarung. Ketika dongeng seperti Snow White (Putri Salju) diadaptasi ke dalam sebuah film, isu terkait konsep kecantikan tidak ditinggalkan. Gambaran utama tentang kecantikan yang disampaikan oleh film tersebut menghadirkan banyak stereotip.

Fokus riset ini adalah bagaimana stereotip kecantikan hadir dalam dua film adaptasi berbasis cerita Snow White yakni Snow White and the Huntsman (2012) dan Mirror-mirror (2012). Metodologi penilitan menggunakan pemikiran Roland Barthes terutama analisis struktural semiotika. Dengan menerapkan konsep dua level signifikansi (denotasi dan konotasi), analisis fokus pada tiga elemen yakni tubuh, pakaian dan karakteristik.
\end{abstract}

Kata kunci: ideologi konservatif, dongeng, mitos, analisis semiotika struktural 


\section{Pendahuluan}

Dongeng anak-anak identik dengan cerita kerajaan seperti putri cantik yang pada akhirnya akan bertemu dengan pangeran tampan. Cerita anak-anak tentang kerajaan tersebut sangat populer di kalangan anak-anak di seluruh dunia. Cerita tersebut bahkan sudah turun temurun diceritakan dari orangtua pada anak-anaknya. Seperti halnya yang tertuang dalam fairy tales (cerita dongeng), dongeng yang turun temurun selalu diceritakan kepada anak-anak dari generasi ke generasi. Cerita dongeng yang berlatar belakang kerajaan pada umumnya berkisah tentang putri cantik yang menikah dengan pangeran tampan, dan peri yang datang menolong putri tersebut.

Cinderella, Snow White (Putri Salju), Sleeping Beauty (Putri Tidur), Beauty and the Beast (Si Cantik dan Si Buruk Rupa) merupakan contoh cerita dongeng yang sangat populer baik di kalangan anak-anak maupun masyarakat dunia. Salah satu perusahaan animasi Hollywood ternama, Walt Disney pernah membuat cerita dongeng dalam bentuk animasi dan meraih kesuksesan besar. Melihat kesuksesan besar yang diraih Walt Disney serta kepopuleran cerita dongeng, para sineas Hollywood kembali membuat dongeng Snow White versi remake.
Pada Maret 2012, Relativy Media merilis film yang diadaptasi dari dongeng Snow White berjudul Mirror Mirror. Film bergenre komedi fantasi berdurasi 106 menit itu dibintangi oleh Lily Collins, Julia Roberts, Armie Hammer, Sean Bean dan Nathan Lane. Film arahan Tarsem Singh tersebut memadukan unsur petualangan, drama dan komedi yang segar. Ditambah dengan eksplorasi cerita yang membuat Mirror Mirror berbeda dengan versi dongengnya.

Kemudian Mei 2012, Universal Pictures merilis film yang sama-sama diadaptasi oleh dongeng serupa berjudul Snow White and The Huntsman (SWATH). Kali ini film arahan Rupert Sanders tersebut memadukan unsur science fiksi, dan action. Film ini menceritakan bagaimana sisi gelap dari Snow White untuk melawan Ratu Ravenna yang telah membunuh ayahnya dan merebut tahta kerajaan. Dari sisi cerita hingga genre, film ini sangat berbeda jauh dari Mirror-mirror. Film yang dibintangi artis papan atas seperti Kristen Stewart, Charlize Theron, Chris hemsworth ini menyajikan Snow White dalam versi thriller dan fiksi untuk konsumsi dewasa.

Dua film adaptasi dari Cerita dongeng tersebut sama-sama merepresentasikan perempuan dalam bentuk yang berbeda. Representasi sendiri menurut Danesi (2010: 3), adalah proses perekaman gagasan, pengetahuan, atau 
pesan secara fisik. Secara lebih tepat ini didefinisikan sebagai penggunaan 'tandatanda' (gambar, suara dan sebagainya) untuk menampilkan ulang sesuatu yang dicerap, diindra, dibayangkan atau dirasakan dalam bentuk fisik. Sementara Hall berpandangan representasi merupakan produksi makna dari konsepkonsep yang ada di pikiran manusia melalui bahasa. Hubungan antara konsep dan bahasa memungkinkan manusia untuk memaknai dunia.

Representation is the production of meaning of the concepts in our minds through language. It is the link between concepts and language which enables us to refer to either the 'real' world of objects, people or events, or indeed to imaginary worlds of fictional objects,people and events (Hall, 1997:17).

Lebih lanjut Hall menjelaskan dua proses dalam sistem representasi, yang pertama adalah konsep-konsep seperti benda, orang maupun peristiwa atau konsep representasi mental yang ada di kepala kita. Kita tidak akan bisa menafsirkan sesuatu tanpa adanya konsep-konsep tersebut. Kemudian proses yang kedua adalah menginterpetasikan konsep-konsep tersebut ke dalam bentuk bahasa. Bahasa merupakan sistem kedua dari representasi yang terlibat dalam keseluruhan proses membangun makna.

Konsep-konsep yang terdapat di pikiran tersebut harus dituangkan dalam bentuk bahasa. Kita harus memiliki peta konseptual yang sama sehingga kita dapat melihat dan memahami dunia melalui sistem klasifikasi yang sama yang ada di pikiran kita. Dengan demikian kita bisa mengartikan, saling bertukar konsep ke dalam bentuk tulisan, suara yang diucapkan, maupun gambar visual. Bahasa merupakan sarana untuk memaknai, menghasilkan, dan mengubah makna. (Hall, 1997:18).

Menuangkan suatu ide ke dalam bentuk visual merupakan salah satu proses agar masyarakat memiliki kesamaan bahasa dalam mengartikan tanda. Karena masyarakat yang memiliki peta konseptual yang sama, akan mempunyai cara yang sama pula dalam mengartikan suatu bahasa. Namun, tanda visual maupun gambar meskipun sangat mirip dengan keadaan ataupun kenyataan sebenarnya, mereka tetap adalah tanda. Tanda tersebut membawa suatu makna yang harus diartikan.

Dalam bahasa visual, ketika hubungan antara konsep dan tanda terlihat cukup mudah. Sebenarnya bahasa visual sangat sulit jika dibandingkan dengan bahasa suara maupun bahasa tulisan. Karena dalam bahasa visual mengandung berbagai macam tanda dan interpretasi yang berbeda-beda hanya dari satu gambar visual saja. Bahasa visual yang banyak terdapat dalam film memiliki arti atau makna yang berbeda tergantung bagaimana konsep-konsep yang ada di pikiran masyarakatnya. 
Konsep tentang representasi tersebut akan dikaitkan dengan citra kecantikan yang direpresentasikan dari kedua film adaptasi tersebut. Snow White and the Huntsman dan Mirror mirror merupakan dua film adaptasi yang menggunakan kecantikan sebagai unsur pembangun cerita.

Kecantikan merupakan hal yang sangat penting dan selalu ditonjolkan dalam dunia visual, khususnya film. Bagi dunia visual, kecantikan bagi seorang wanita merupakan syarat yang wajib dimiliki untuk menggambarkan perempuan secara sempurna. Unsurunsur fisik yang selalu ditonjolkan dalam film seakan semakin mempertegas bahwa penampilan fisik adalah segalanya, walaupun disampaikan secara implisit.

Hal ini tentu dapat berpengaruh bagi masyarakat, apalagi film merupakan salah satu produk budaya yang berkembang dan populer di kalangan masyarakat. Film seakan mengajarkan kepada masyarakat bahwa definisi cantik adalah seperti yang digambarkan oleh film. Film maupun produk komunikasi visual menempatkan kecantikan menurut cara pandang laki-laki. Tidak hanya perempuan saja, laki-laki pun juga digambarkan “cantik". Namun, kecantikan pada pria tentunya berbeda. Dalam media komunikasi visual khususnya film, pria dengan tubuh tinggi tegap, berotot dan besar dianggap cantik. Sama halnya dengan perempuan, unsur fisik pada pria menjadi salah satu daya tarik utama dan selalu ditonjolkan dalam film.

Gambaran tentang perempuan dan laki-laki dalam film pada akhirnya menjadi suatu bahasa tertentu yang ditangkap oleh masyarakat. Fungsi bahasa adalah menarasikan atau merepresentasikan dunia kepada masyarakat manusia. Akan tetapi, bahasa hanya mungkin berfungsi bila ada sesuatu yang ditangkap lewat bahasa itu dari realitas dunia (Reality), inilah yang disebut citra (image). (Pilliang, 2009: 80)

Dengan kata lain, citra merupakan gambaran, kesan, perasaan yang digambarkan atau dirasakan lewat indra yang ada dalam benak atau pikiran seseorang. Film merupakan sarana atau media yang merepresentasikan kejadian yang ada di dunia nyata ke dalam bentuk citra pada tokoh karakternya. Seperti pada citra perempuan maupun laki-laki yang direpresentasikan oleh media. Maskulinitas pada pria tumbuh dan berkembang menurut budaya patriarki pada awal perkembangan film di dunia. Dalam budaya patriarki, seorang laki-laki harus kuat, memimpin dan tidak banyak menunjukkan emosinya.(Benshoff \& Griffin, 2009: 258).

Peranan citra yang jauh lebih berkuasa akibat peranan kemajuan sains dan teknologi menyebabkan terjadinya perubahan pada citra perempuan dan lakilaki di film khususnya pada pembentukan citra kecantikan. Hal ini membuat 
kecantikan bukan lagi soal rasa atau selera namun telah menjadi salah satu budaya di masyarakat. Standar kecantikan pada akhirnya berkembang sesuai dengan perubahan zaman dan kebudayaan tersebut. Sehingga melahirkan bentukbentuk kecantikan yang hampir serupa antara laki-laki dan perempuan.

Film juga banyak menampilkan stereotip yang secara implisit diselipkan kedalamnya. Dalam film adaptasi SWATH dan Mirror mirror ini, stereotip yang diperlihatkan dan sangat menonjol adalah tentang kecantikan. Bagaimana kecantikan menjadi sangat essensial serta sebagai pemicu dari semua permasalahan dan konflik yang muncul. Dari dua film adaptasi tersebut, stereotip kecantikan yang ditampilkan dalam film masih melulu soal tubuh dan fisik.

\section{Rumusan Masalah}

Kedua film tersebut berasal dari dongeng yang sama, dan penggambaran kecantikan yang ditampilkan dari kedua film tersebut juga sama. Stereotip tentang kecantikan masih merupakan isu utama bagi perempuan, baik itu di dunia visual maupun dalam dongeng. Film ini dipilih karena kedua film adaptasi tersebut memiliki penggambaran kecantikan dari karakter tokoh yang berbeda. Karena penggambaran yang berbeda itulah maka akan ditemukan tanda-tanda maupun simbol-simbol yang merepresentasikan kecantikan. Kemudian pertimbangan lain adalah kedua film tersebut sama-sama dirilis pada tahun 2012 dengan selang waktu yang tidak terlalu lama.

Berdasarkan argumen diatas, maka perumusan masalah untuk penelitian kali ini adalah bagaimana representasi kecantikan wanita dalam film Snow White and the Huntsman dan Mirror mirror? Lalu yang kedua adalah bagaimana stereotip atas kecantikan dimunculkan dalam film adaptasi tersebut?

\section{Tinjauan Pustaka}

\section{Representasi Kecantikan dalam Cerita Dongeng}

Cerita dongeng merupakan bentuk cerita fantasi yang tokoh dan figur yang diceritakan tidak benar-benar ada di dunia nyata. Cerita dongeng biasa disebut dongeng dalam bahasa indonesia. Cerita dongeng bercerita tentang peri, penyihir, putri, pangeran, raksasa, dan sebagainya. Cerita dongeng telah ada semenjak ribuan tahun lalu dan diceritakan secara turun temurun dari generasi ke generasi di seluruh dunia. Seiring dengan perubahan zaman dan cerita yang disampaikan dari mulut ke mulut, Cerita dongeng pun mengalami evolusi cerita, karakter dan penggambaran tokohnya.

Dongeng anak khususnya yang berlatar belakang monarki atau kerajaan selalu identik dengan perempuan. Contohnya, seperti yang terlihat pada kisah Cinderella, Sleeping Beauty, Beauty 
and the Beast. Dongeng dan perempuan ibarat satu cerita yang akan selalu ditampilkan dalam berbagai dongeng anak, baik dongeng lokal maupun luar negeri. Perempuan dalam dongeng selalu digambarkan tak ubahnya seperti perempuan dalam stereotipe visual media. Mengutip Elda, (http://matavisualsielda. wordpress.com/2011/06/01/rekonstruksicitra-wanita-dalam-media/, akses 1 oktober 2013), Stereotip visual wanita adalah berkulit putih, bertubuh langsing dan berparas cantik. Konstruksi seperti ini berurat akar dalam bentuk mainan anakanak sampai dengan iklan perawatan bagi wanita berumur,yang notabene dimaksudkan untuk "memelihara kecantikan kulit"

Karakter utama perempuan selalu digambarkan protagonis dengan wajah cantik, paras menarik, berhati lembut dan baik hati. Sedangkan perempuan buruk rupa merupakan karakter antagonis dengan sifat jahat, iri, selalu menyiksa tokoh utama yang berwajah cantik. Kemudian pada akhirnya putri cantik akan bertemu dengan pangeran yang sangat tampan dan menikah. Cerita dongeng anak seolah menguatkan jika putih itu cantik, dan cantik selalu baik. Sedangkan hitam itu buruk rupa dan selalu menjadi jahat. Padahal tidak selamanya putih itu baik dan hitam itu jahat.

Tidak hanya perempuan, pria dalam dongeng pun harus berwajah tampan.
Walaupun pria tidak menjadi tokoh utama dalam cerita, namun kehadiran pria dalam dongeng selalu distereotipkan sebagai karakter heroik berwajah tampan yang selalu berhasil menolong perempuan cantik keluar dari penderitaan. Oleh karena itu seorang pangeran dalam dongeng harus mempunyai tubuh yang kuat dan tangguh agar berhasil menyelamatkan putri. Disini, kecantikan pada pria terlihat dari kekuatan serta ketangguhannya. Kekuatan tersebut distereotipkan melalui tubuh yang kekar, besar, kuat dan berotot. Sehingga kekuatan dalam hal ini dilihat sebagai salah satu unsur kecantikan pada pria yang ditunjukkan melalui fisik.

Standar kecantikan antara laki-laki yang terdapat pada media khususnya film merupakan suatu imaji tentang keindahan atau estetika yang terdapat pada tubuh laki-laki maupun perempuan. Ketika kita mengapresiasi sesuatu yang berhubungan dengan estetika, biasanya akan mengartikan bahwa nilai yang ada didalamnya akan merujuk pada suatu keindahan.

When we say that we appreciate something ( a work of art, a photograph) for "aesthetic" reasons, we usually imply that the value of the work resides in the pleasure it brings us through its beauty,its style,or the creative and technical virtuosity that went into its production. We no longer think of beauty as a universal shared set of qualities. Contemporary concepts of aesthetics emphasize the ways in which the criteria for what is 
beautiful and what is not are based on taste which is not innate but rather culturally spesific (Sturken \& Cartwright, 2009: 56).

Seperti yang terdapat pada makna tentang kecantikan tersebut bukan berdasarkan rasa, melainkan berdasarkan pada kebudayaan. Hal yang sama juga terlihat pada representasi kecantikan pada tubuh laki-laki dan perempuan. Bahwa sebenarnya kecantikan pada tubuh lakilaki dan perempuan muncul karena terjadinya pergeseran budaya terhadap makna kecantikan.

Hal ini menunjukkan bahwa cerita anak bukanlah cerita yang netral. Karena selain bertujuan untuk menghibur, ada nilai-nilai lain yang sengaja dimasukkan kedalam unsur cerita anak. Seperti penggambaran tokoh misalnya. Anakanak telah terbiasa dengan dongeng monarki yang menceritakan bahwa seorang putri pasti selalu cantik dan seorang pangeran sudah pasti harus tampan. Kemudian pada akhirnya putri cantik dan pangeran tampan harus menikah, itulah baru happy ending. Pikiran anak-anak yang semenjak kecil dijejali dengan penggambaran karakter putri di negeri dongeng. Hingga pada akhirnya, ketika beranjak dewasa sang anak akan membentuk persepsi ketika dewasa dirinya akan secantik putri dan pangeran tampan akan datang menyelamatkan kehidupannya.

Walaupun telah mengalami perubahan zaman, kultur, dan cerita. Namun kecantikan masih merupakan isu utama yang diangkat dalam Cerita dongeng. Diceritakan bahwa seorang putri itu cantik, cantik adalah sesuatu yang indah dan memikat. Lalu seorang pangeran itu tampan dan gagah perkasa, kekuatannya ditunjukkan lewat tubuh besarnya dan kepiawaiannya dalam berkelahi. Karena cantik, orang-orang menyukainya dan pangeran akan menyukainya. Secara implisit, dongeng Snow White seolah mengajarkan bahwa penampilan fisik merupakan modal utama bagi laki-laki dan perempuan. Perempuan harus cantik agar dapat menarik perhatian dan lakilaki harus kuat dan tampan agar dapat melindungi dan menyelamatkan putri.

Media maupun dongeng selalu menggunakan kecantikan sebagai daya tarik utama baik untuk laki-laki maupun perempuan. Hal ini dapat berpengaruh kepada pola pikir masyarakat khususnya anak-anak. Bagi anak-anak, apa yang direpresentasikan oleh media merupakan contoh perempuan atau laki-laki yang ideal.

Mitos Kecantikan dan Film Populer: antara stereotype dan positive images

Kecantikan identik dengan keindahan, namun keindahan sendiri sebenarnya bersifat relatif. Persepsi orang tentang kecantikan maupun keindahan tentu saja berbeda. Karena setiap orang 
mempunyai selera sendiri untuk menentukan batas kecantikan atau keindahan menurut standar mereka. Namun, ketika media mulai banyak merepresentasikan bentuk - bentuk kecantikan melalui produk tayangan media. Maka makna kecantikan pun berubah. Kecantikan atau keindahan adalah seperti apa yang ditunjukkan oleh media. Karena efek media yang begitu besar terutama terhadap pola pikir masyarakat tersebut. Pada akhirnya persepsi kecantikan pada setiap orang menjadi sama.

Media mempunyai peran besar dalam membentuk stereotipe atas kecantikan. Kecantikan menurut media selalu dicirikan dengan tampilan fisik yang menarik. Namun kecantikan yang dicirikan oleh media banyak diwujudkan dalam bentuk keindahan wanita. Menurut Naomi Wolf, mitos kecantikan menceritakan tentang kualitas yang disebut "cantik" yang secara objektif dan universal ada. Perempuan harus mewujudkan hal itu dan laki-laki ingin memiliki wanita yang memiliki hal tersebut.

The beauty myth tells a story: the quality called "beauty" objectively and universally exist. Women must want to embody it and men must want to possess women who embody it. This Embodiment is an imperative for women and not for men, which situation is necesarry and natural because it is biological, sexual, and evolutionary : Strong men battle for beautiful women, and beautiful women are more

\section{reproductively successful.(Wolf,} 2002: 12)

Wolf berpendapat kecantikan merupakan stereotip yang dibangun berdasarkan tampilan fisik. Jika perempuan cantik, maka pria akan memperebutkannya, dan perempuan tersebut akan dimudahkan dalam segala hal. Stereotip tentang kecantikan tersebut sering dipraktekan media melalui tayangan-tayangan baik film maupun televisi.

Stereotip sering dimunculkan dalam film atau tayangan media lainnya. Stereotip tersebut biasanya digunakan untuk menandai suatu kelompok atau golongan tertentu sehingga mempunyai ciri khas tersendiri. Stereotipe sendiri sebenarnya berasal dari penandaan atau label dari suatu kelompok tertentu didalam masyarakat. Karena adanya penandaan dari setiap kelompok masyarakat itulah yang menyebabkan setiap orang yang memiliki ciri tertentu. Sehingga mendapat 'sebutan' dan perlakuan yang berbeda dalam lingkungan sosial.

Stereotip tersebut menjadi bermasalah ketika digunakan untuk mendukung kelompok - kelompok tertentu atas orang lain. Tanda-tanda yang dibentuk dalam stereotip tersebut terkadang menimbulkan kesan negatif bagi suatu kelompok masyarakat tertentu. Stigma yang ditimbulkan oleh stereotip 
Dira Elita, Mempertanyakan Stereotip Kecantikan Mempertanyakan Stereotip Kecantikan (Analisis Semiotika tentang Representasi Kecantikan dalam Film Adaptasi Snow White and the Huntsman (2012) dan Mirror Mirror (2012))

tersebut berdampak bagi suatu kelompok masyarakat, sehingga memiliki label ataupun sebutan tertentu yang dianggap negatif. Untuk merubah stigma negatif yang ditimbulkan dari stereotip tersebut, akhirnya dibentuklah Positive Image untuk merubah atau membalikkan label negatif stereotip. Positive image ini banyak digunakan dalam film terutama untuk mengubah pandangan masyarakat tentang suatu stereotip tertentu yang berkembang di lingkungan sosial.

\section{Metode Penelitian}

Penelitian ini menggunakan paradigma kritis. Paradigma kritis adalah paradigma yang mendefinisikan ilmu komunikasi sebagai suatu proses yang secara kritis mengungkap struktur sebenarnya dibalik ilusi yang ditampakan di dunia materi dengan tujuan membentuk kesadaran sosial agar merubah kondisi kehidupan manusia. (mengungkap suatu ideologi apa yang tersembunyi dalam produk tertentu). Pendekatan yang digunakan dalam penelitian kali ini adalah pendekatan strukturalis. Menurut Budiman (2011:9), Pendekatan strukturalis memberikan perhatian terhadap kode-kode yang digunakan untuk menyusun makna. Strukturalisme merupakan suatu pendekatan yang secara khusus memperhatikan struktur karya sastra atau seni. Fenomena kesastraan dan estetik didekati sebagai sistem tanda-tanda
Peneliti menggunakan analisis semiotika karena penelitian ini berusaha untuk mengungkap makna dibalik tandatanda yang ditampilkan dalam film adaptasi. Film termasuk salah satu media yang menggunakan tanda sebagai media komunikasi untuk menyampaikan pesan. Dengan menggunakan analisis semiotika, peneliti ingin melihat makna-makna tanda apa saja yang disampaikan dari kedua film adaptasi tersebut.

Pada dasarnya semiotika bersifat kualitatif interpretatif, yaitu hanya memfokuskan pada tanda dan teks sebagai kajian penelitiannya. Serta bagaimana makna yang dibangun berdasarkan tanda dan teks tersebut. Kode-kode yang mengandung makna tersebut akan dijelaskan secara deskriptif berdasarkan interpretasi atau penafsiran dari tanda-tanda dan teks dalam film.

Semiotika merupakan suatu ilmu yang mempelajari perilaku berdasarkan tanda-tanda dan bagaimana cara tanda tersebut bekerja. Penelitian ini menggunakan semiotika pemikiran Barthes. Ada pun inti pemikiran Barthes adalah gagasan tentang dua tatanan pertandaan ( order of significations) yakni denotasi dan konotasi..

Tatanan denotasi menggambarkan relasi antara penanda dan petanda didalam tanda, dan antara tanda dengan referennya dalam realitas eksternal. Ada pun konotasi dipakai untuk menjelaskan salah satu dari tiga cara kerja tanda dalam 
tatanan pertandaan kedua. Konotasi menggambarkan interaksi yang berlangsung tatkala tanda bertemu dengan perasaan atau emosi penggunanya dan nilai-nilai kulturalnya. Barthes menegaskan bahwa setidaknya pada foto, perbedaan antara konotasi dan denotasi menjadi jelas. Denotasi merupakan reproduksi mekanis diatas film yang ditangkap kamera. Konotasi adalah bagian manusiawi dari proses ini mencakup seleksi atas apa yang masuk dalam bingkai (Frame), fokus, rana, sudut pandang kamera, mutu film (Fiske, 2011:118-119)

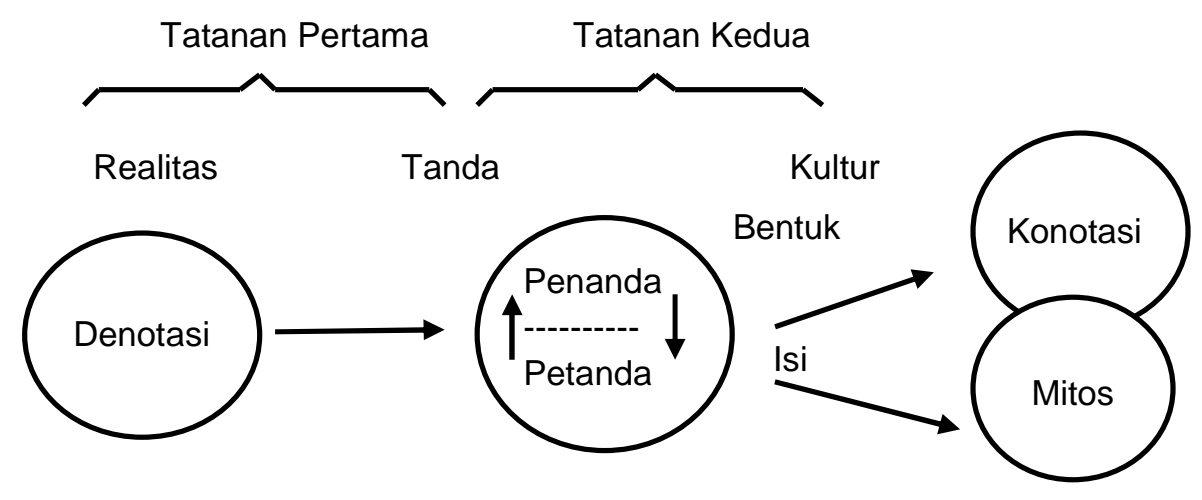

\section{Gambar 1. Dua Tatanan Pertandaan Barthes (dalam Fiske, 2011: 122)}

\begin{abstract}
Barthes memasukkan mitos
\end{abstract} sebagai cara kedua dari tiga cara mengenai bekerjanya tanda pada tatanan kedua. Mitos merupakan cara berpikir terhadap sesuatu dari suatu kebudayaan tertentu. Mitos adalah suatu cara untuk mengkonseptualisasikan atau memahami sesuatu. Cara kerja pokok mitos adalah menaturalisasikan sejarah. Ini menunjukkan kenyataan bahwa mitos sebenarnya merupakan produk kelas sosial yang mencapai dominasi melalui sejarah tertentu: maknanya, peredaran mitos tersebut mesti dengan membawa sejarahnya. Namun operasinya sebagai mitos mencoba menyangkal hal tersebut dan menunjukan maknanya sebagai alami dan bukan bersifat historis atau sosial.
Konotasi dan mitos merupakan cara pokok tanda-tanda berfungsi dalam tatanan kedua pertandaan, yakni tatanan tempat berlangsungnya interaksi antara tanda dan pengguna/budayanya yang sangat aktif ( Fiske, 2011: 122-126).

Bahasa membutuhkan kondisi tertentu untuk menjadi mitos yang secara semiotis dicirikan dengan hadirnya sebuah tatanan signifikasi yang disebut sistem semiologis tingkat kedua. Penanda-penanda berhubungan dengan petanda-petanda sehingga menghasilkan tanda baru. Selanjutnya, tanda pada tatanan pertama ini akan berubah menjadi penanda yang akan behubungan pada tatanan kedua. Pada tatanan signifikasi kedua inilah mitos terbentuk. Menurut Barthes, aspek 
Dira Elita, Mempertanyakan Stereotip Kecantikan Mempertanyakan Stereotip Kecantikan (Analisis Semiotika tentang Representasi Kecantikan dalam Film Adaptasi Snow White and the Huntsman (2012) dan Mirror Mirror (2012))

material mitos, yakni penanda-penanda pada sistem tatanan kedua diebut retorik atau konotator-konotator, yang tersusun dari tanda-tanda pada sistem pertama sementara petanda-petandanya dapat dinamakan fragmen ideologi (seperti dikutip Budiman, 2011: 38)

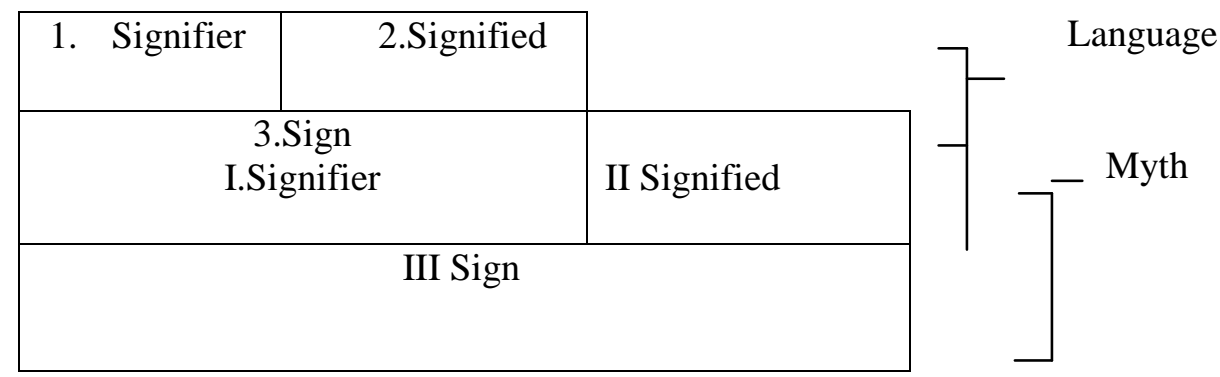

Gambar 2. Penanda Petanda (seperti dikutip dari Budiman, 2011: 39)

Setiap tuturan (speech) baik itu yang berupa sesuatu yang tertulis atau representasi, verbal atau visual dapat menjadi mitos. Yang dapat berarti tidak hanya wacana tertulis saja. Namun baik itu fotografi, film, pertunjukkan, olahraga maupun makanan dapat dibaca sebagai mitos.
Barthes mengembangkan sebuah model relasi antara apa yang disebutnya sistem, yaitu perbendaharaan tanda (kata,visual,gambar,benda) dan sintagma yaitu cara pengkombinasian tanda berdasarkan aturan main tertentu. (Eco dalam Pilliang, 2012: 303).

Tanda

Denotasi

Konotasi (Kode) Mitos

Gambar 3. hubungan Tanda, Denotasi, Konotasi, dan Mitos (dalam Pilliang, 2012: 305)

\section{Hasil dan pembahasan}

Dalam film adaptasi SWATH terdapat banyak sekali isu-isu kecantikan yang direpresentasikan dalam bentuk scene. Yang terdiri dari kumpulan shotshot, dialog yang diucapkan, dan sikap dari tiap karakter yang ditunjukan untuk merepresentasikan kecantikan. Selain itu pencahayaan, visualisasi, serta kostum yang digunakan juga turut berperan dalam pembentukan isu kecantikan di film adaptasi ini. Film ini banyak menggunakan teknik visualisasi seperti medium shot, medium long shot, full shot, dan high angle. Dialog yang digunakan merepresentasikan simbol kecantikan dalam bentuk kalimat seperti perintah, pujian, dan sebagainya.

Setiap tanda akan diidentifikasi oleh peneliti berdasarkan tiga kategori kecantikan yaitu tubuh, kostum, dan sifat. Untuk dikembangkan dalam tahap 
denotasi. Selanjutnya, tahap tersebut akan diuraikan secara sistematis dan berlanjut pada tahap berikutnya yaitu konotasi dan mitos.

Representasi tentang kecantikan dalam film adaptasi ini nantinya akan

Tabel Representasi tentang Kecantikan dalam film SWATH dan Mirror-Mirror

\begin{tabular}{|c|c|}
\hline Tema & Elemen \\
\hline A. Tubuh & $\begin{array}{ll}\text { - } & \text { Wajah } \\
\text { - } & \text { Tubuh Gadis } \\
\text { - } & \text { Tua merupakan musibah } \\
\text { - } & \text { Cantik itu menonjol / Unordinary }\end{array}$ \\
\hline B. Kostum & $\begin{array}{ll}\text { - } & \text { Identitas dan memperkuat karakter } \\
\text { - } & \text { Menunjukan keindahan } \\
\text { - } & \text { Menonjolkan yang tertutup }\end{array}$ \\
\hline C. Sifat/ Karakter & $\begin{array}{ll}\text { - } & \text { Iri } \\
\text { - } & \text { Balas dendam } \\
\text { - } & \text { Kekuatan / kelembutan } \\
\end{array}$ \\
\hline
\end{tabular}

Kecantikan pada umumnya terlihat dari bentuk fisik yang indah dan menarik. Hal tersebut biasanya direpresentasikan dalam bentuk tubuh yang langsing, kulit yang mulus, dan wajah yang rupawan. Semua unsur-unsur kecantikan tersebut terdapat pada tubuh muda. Dan untuk menonjolkan kecantikan-kecantikan yang terdapat pada tubuh muda tersebut, kostum menjadi sarana untuk menutupi sekaligus menampakkan keindahan pada tubuh tersebut. Kostum selain berfungsi untuk menutupi anggota tubuh, juga berguna untuk menunjukan ciri khas atau identitas dari pemakai kostum ataupun tokoh tersebut. dilihat melalui tiga hal, yaitu tubuh, kostum, dan sifat/karakter. Masingmasing tema tersebut memiliki elemenelemen masing-masing (Lihat Tabel)

- Kekuatan / kelembutan

\section{Kecantikan tubuh}

Bentuk kecantikan yang ditampilkan lewat tubuh seperti yang ditampilkan pada film SWATH scene 2. Pada scene itu, Ravenna membunuh Raja setelah sebelumnya menceritakan bagaimana penderitaannya ketika dicampakkan oleh seorang raja pada masa lalunya. Dalam scene tersebut, terlihat bagaimana kemudaan pada perempuan merupakan hal yang sangat penting, karena jika perempuan tersebut beranjak tua maka laki-laki akan membuang dan meninggalkannya. Hal ini terlihat dari dialog yang diucapkan Ravenna, "When a woman stay young and beautiful forever the worlds is hers". 
Dira Elita, Mempertanyakan Stereotip Kecantikan Mempertanyakan Stereotip Kecantikan (Analisis Semiotika tentang Representasi Kecantikan dalam Film Adaptasi Snow White and the Huntsman (2012) dan Mirror Mirror (2012))

Dialog tersebut makin menegaskan bahwa perempuan tidak boleh menjadi tua, karena jika menjadi tua, semua yang pernah dimilikinya semasa muda akan hilang. Representasi kecantikan yang ditunjukkan lewat dialog yang diucapkan oleh Ravenna

Selain ditampilkan dalam Dialog, kecantikan tubuh juga terlihat pada scene 3. Pada scene ini tidak terdapat dialog seperti pada scene sebelumnya. Kecantikan lewat tubuh diperlihatkan lewat visualisasi yang menampakkan Snow White yang berada dalam penjara selama bertahun-tahun dengan tampang lusuh dan kotor. Namun begitu, kecantikannya tetap terlihat dan tidak memudar. Visualisasi yang menunjukkan kecantikan tubuh Snow White ditunjukkan ketika Snow White melihat sinar lewat jendela kecil di penjara. karena penjara yang terbuat dari batu sehingga pencahayaan menjadi agak gelap dan minim cahaya. Dengan menggunakan medium close up dan gerakan kamera zoom in, sosok tubuh Snow white terutama wajahnya terlihat sangat ditonjolkan. Ditambah pencahayaan yang terang hanya di bagian wajah Snow White hingga dada menunjukkan makna bahwa walaupun dikurung selama bertahuntahun, kecantikan Snow White tetap menonjol.

Kecantikan tubuh lainnya yang terlihat dalam film SWATH adalah pada scene 3, ketika Ravenna sedang bercermin di cermin ajaibnya. Dalam scene ini, representasi kecantikan tubuh diperlihatkan melalui visualisasi dan dialog. pada visualisasi, tampak Ravenna sedang bercermin sambil memegang wajahnya yang mulai menua dan berkeriput. Ukuran gambar yang digunakan close up sehingga nampak jelas bagaimana keriput yang ada di wajah Ravenna serta ekspresinya yang sedih. Kemudian Finn datang sambil memeluk pundak ravenna serta menghiburnya. Dalam dialog tersebut, Finn berusaha menghibur ravenna. Namun pembicaraan tersebut dipotong oleh Ravenna yang mengatakan bahwa dirinya tampak tua. Finn menyangkal dan berkata bahwa kakaknya tersebut hanya nampak lelah.

Pencahayaan yang gelap dan sudut pandang yang diambil lewat pantulan bayangan di cermin ajaib semakin menguatkan bahwa perempuan dengan keriput dan penuaan tidak dianggap cantik dan merupakan musibah dan sumber kesedihan bagi perempuan. Hal ini juga dianggap sebagai wujud buruk rupa seorang perempuan. seperti yang diungkapkan Wolf, persaingan perempuan telah menjadi bagian dari mitos kecantikan. Hal ini menyebabkan perempuan terbagi satu sama lain. Perempuan yang termasuk dalam bagian muda dan perawan adalah cantik. Sedangkan penuaan pada wanita adalah tidak cantik. 
Competition between women has been made part of the myth so that women will be divided from one another. Youth and (until recently) virginity have been "beautiful" in women since they stand for experiental and sexual ignorance. Aging in women is "Unbeautiful" since women grow more powerful with time, and since the links between generations of women must always be newly broken: older women fear young ones, young women fear old, and the beauty myth tuncates for all female life span. Most urgently, women's identity must be premised upon our "beauty" that we will remain vulnerable to outside approval, carrying the vital sensitive organ of self-esteem exposed to the air (Wolf, 2002: 14)

Dalam scene tersebut terlihat bagaimana mitos kecantikan yang ditulis oleh Wolf dalam bukunya direpresentasikan. Ravenna takut menjadi tua karena tua identik dengan jelek. Oleh karena itu dia terobsesi dengan kemudaan. Hubungan antara si tua dan si muda dalam film Snow White juga direpresentasikan tidak baik. Ravenna meski terlihat muda dan cantik, namun sebenarnya tua jika tidak menggunakan sihir. Dia membenci Snow White yang muda dan cantik tanpa perlu menggunakan sihir untuk tetap cantik seperti dirinya.

\section{Kostum}

Scene yang menampilkan kecantikan melalui kostum pada film adaptasi SWATH terdapat pada scene 5 .
Scene tersebut menampilkan William yang menyerang pasukan istana dengan menggunakan panah api sehingga menyebabkan kereta kuda yang dinaiki pasukan istana terjatuh. Kecantikan yang ditunjukkan lewat kostum tersebut ditampilkan lewat visualisasi, tidak ada dialog yang mendukung kecantikan dalam scene ini. dalam scene tersebut, William mengenakan baju lengan panjang dari bahan kulit dilengkapi dengan rompi yang juga berfungsi untuk menyimpan senjata.

William menggunakan baju berlengan panjang dari bahan kulit dan rompi yang menutupi dadanya, serta ikat pinggang untuk menyimpan senjata berupa pedang dan panah. Penggunaan baju berbahan kulit ini menimbulkan kesan macho, gagah, berani, dan kuat karena jaket kulit yang tahan kondisi dan cuaca apapun.

Kesan kuat dan gagah yang ditimbulkan dari jaket kulit direpresentasikan kedalam bentuk kostum William. Baju berbahan kulit yang dipakai William memiliki makna kuat, berani, dan gagah namun tetap bergaya. Penggunaan baju berbahan kulit ini pun berfungsi untuk menonjolkan karakter William yang pemberontak, kuat, dan berani. Selain itu juga membentuk tubuh Wiliam menjadi lebih besar dan tegap.

Properti berupa panah dan pedang yang digunakan william untuk membantai prajuritnya adalah untuk menunjukkan kekuatan dan keperkasaan laki-laki. Laki- 
Dira Elita, Mempertanyakan Stereotip Kecantikan Mempertanyakan Stereotip Kecantikan (Analisis Semiotika tentang Representasi Kecantikan dalam Film Adaptasi Snow White and the Huntsman (2012) dan Mirror Mirror (2012))

laki yang memegang senjata dianggap kuat dan perkasa karena pandai untuk melindungi diri dan melawan hal-hal yang membahayakan dirinya. Di sinilah representasi kecantikan lewat kostum dibangun. Kostum menunjukkan simbolsimbol makna yang berkaitan dengan identitas maupun karakteristik seseorang. Dalam perfilman, khususnya film Hollywood, tubuh kekar, pandai menggunakan senjata merupakan hal yang dianggap cantik. Oleh karena itu dalam film-film action ataupun laga, tokoh laki-lakinya selalu berbadan besar, tegap dan piawai menggunakan senjata.

Selain itu, pencahayaan yang digunakan ketika menyorot William seusai bertanding adalah dengan menggunakan cahaya belakang atau backlight. Menyorot obyek dengan cahaya belakang biasanya dimaksudkan untuk menonjolkan bentuk ataupun shape dari objek tersebut. Dalam film ini mengambil shot dengan backlight dimaksudkan untuk menampakkan bentuk tubuh William yang besar, kuat dan gagah dibalut kostum kulit yang dipakainya. Selain itu adanya kereta kuda yang terbakar dibelakangnya turut menjadi penanda bahwa William merupakan laki-laki yang senang bertarung dan jantan.

Representasi kecantikan lewat kostum juga ditunjukkan pada film adaptasi Mirror mirror yang terdapat pada scene 3. Pada scene tersebut, Snow White dan pangeran bertemu secara tidak sengaja di acara pesta dansa yang diadakan Ratu. dalam pesta dansa tersebut, semua tamu undangan mengenakan kostum yang unik. Namun, Snow White dan pangeran mengenakan kostum yang berbeda dari para tamu yang lain.

Si cantik dalam hal ini adalah pangeran dan Snow White yang terlihat begitu menonjol diantara para tamu undangan. Penggambaran yang terlihat menonjol tersebut tidak hanya dari kostum saja, namun juga terlihat dari properti yang digunakan, serta gesture atau gerakan pangeran yang tetap ingin berdansa dengan Snow White sehingga semakin menonjolkan perbedaan antara si cantik pada pesta dansa tersebut. Dalam pesta dansa yang memakai kostum tersebut, para tamu menggunakan kostum aneh bahkan tidak lazim, namun Snow White dan pangeran tetap menggunakan kostum normal seperti biasa tanpa aksesoris dan tambahan apapun di kostum maupun penampilannya.

Representasi kecantikan ditunjukkan lewat visualisasi kostum.ukuran gambar yang digunakan adalah medium long shot untuk menujukkan bagaimana penampilan dan kostum Snow White dan pangeran yang terlihat berbeda diantara para tamu undangan yang lain. 


\section{Sifat}

Kecantikan lewat sifat terdapat pada film SWATH ditunjukkan pada scene 1. Kecantikan yang ditunjukkan lewat sifat dalam scene ini dtunjukkan melalui visualisasi. Scene ini menampilkan ketika Ravenna yang hendak dinikahi ayah Snow White berjalan menuju altar. Dengan diiringi oleh pengawal disampingnya dan Snow white di belakangnya, Ratu berjalan dengan langkah tegap dan pandangan lurus kedepan. Namun ketika menyadari bahwa dirinya bukan menjadi pusat perhatian, senyum yang tadinya mengembang di wajahnya memudar, berganti dengan ekspresi datar. Scene ini menggunakan ukuran gambar medium close up, sehingga terlihat bagaimana profil ravenna dari kepala hingga dada serta ekspresi wajah Ravenna.

Pada scene ini, kecantikan dapat terlihat dari sifat yang dimilikinya. Walaupun memiliki wajah yang samasama cantik, namun akan menjadi berbeda jika sifat yang dimiliki sangat bertolak belakang. Dalam hal ini Snow White yang sudah lebih dikenal sebagai gadis cantik yang baik hati akan lebih familiar oleh orang-orang disekitarnya daripada Ravenna. Meski berwajah cantik, orang-orang tidak mengetahui bagaimana sifat yang dimilikinya. Sehingga Snow White lebih menarik perhatian daripada Ravenna.
Inilah yang menyebabkan kecantikan berkaitan dengan sifat. Karena dengan wajah yang sama-sama cantik dan menarik, namun karakter atau sifat yang lebih dulu dikenal di masyarakat akan lebih familiar sehingga dengan mudah menarik perhatian.

Representasi kecantikan melalui sifat yang menonjol dalam film Mirror mirror terdapat pada scene 4. Dalam scene tersebut, Brighton datang memberitahukan Ratu bahwa Snow White telah dibunuh dihutan sesuai dengan permintaannya. Ratu merasa senang dan tenang karena telah berhasil menyingkirkan saingannya. Representasi kecantikan yang ditunjukkan melalui kekuasaan itu ditampilkan pada dialog dan visual. Dimana dalam dialog Ratu merasa sangat puas dan senang. Ratu juga selalu memuji Brighton atas usahanya membunuh Snow White. Intonasi yang digunakan dalam dialog tersebut menggunakan intonasi tinggi yang menunjukkan kebahagiaan dan kelegaan.

Dari scene yang ditampilkan, serta dialog yang diucapkan terlihat bagaimana sifat Ratu yang berusaha menyingkirkan Snow White yang menjadi saingannya. Representasi kecantikan ditunjukkan lewat sifat yaitu kekuatan yang disimbolkan melalui kekuasaan. Jika perempuan mempunyai kekuasaan, maka akan dengan mudah melakukan hal apa saja, termasuk hal-hal buruk yang 
Dira Elita, Mempertanyakan Stereotip Kecantikan Mempertanyakan Stereotip Kecantikan (Analisis Semiotika tentang Representasi Kecantikan dalam Film Adaptasi Snow White and the Huntsman (2012) dan Mirror Mirror (2012))

berkebalikan dengan citra kecantikan dalam dirinya bahkan tidak masuk akal.

Kekuasaan dalam hal ini didapat dengan melakukan hal-hal yang tidak masuk akal atau yang tidak logis. Untuk memperoleh kekuasaan tersebut, kecantikan menjadi salah satu senjata utama untuk mendapatkan kekuasaan atau kemenangan tersebut. Sehingga kecantikan dalam hal ini erat kaitannya dengan kekuatan. Contohnya dapat ditemui pada kehidupan sehari-hari, terutama pada tayangan media. Tidak sedikit artis yang menggunakan cara yang tidak masuk akal untuk meraih popularitas. Cara yang tidak masuk akal disini diartikan dengan membuat sensasi, atau berita yang menghebohkan masyarakat sehingga menjadi perbincangan tidak hanya di kalangan masyarakat, namun juga di media itu sendiri. Hal tersebut tentunya dapat berpengaruh kepada tawaran-tawaran pekerjaan yang semakin meningkat.

\section{Penutup}

Dari analisis dan pembahasan yang telah dilakukan sebelumnya, ditemukan adanya mitos-mitos kecantikan dalam film Snow White and the Huntsman dan Mirror mirror yang sangat dominan. Temuan tersebut terdapat dalam dialog, visualisasi, shot kamera yang digunakan maupun teknik pencahayaan yang digunakan.
Terdapat tiga temuan mitos kecantikan pada kedua film adaptasi tersebut. Pertama, mitos kecantikan yang ditampilkan melalui tubuh banyak ditemukan pada kedua film adaptasi tersebut. Kecantikan dilihat melalui tubuh baik pada tubuh laki-laki maupun perempuan. Pada tubuh perempuan, tubuh yang dianggap cantik adalah tubuh muda yang belum menunjukkan tandatanda penuaan karena penuaan dianggap buruk rupa. Sedangkan kecantikan pada pria terlihat dari tubuh yang kekar, besar, dan gagah. Oleh karena itu pada film Snow White and the Huntsman, karakter pemburu, dan pangeran William memiliki tubuh yang besar, kuat dan pandai bertarung dan memegang senjata. Walaupun tidak ditunjukkan secara eksplisit, namun kecantikan lewat tubuh tetap terlihat dan menonjol.

Dalam kedua film adaptasi tersebut, tolak ukur kecantikan dari seorang wanita adalah seberapa muda wajah dan tubuh yang dimilikinya. Karena jika perempuan tersebut menjadi tua atau menunjukkan tanda-tanda penuaan, hal tersebut dianggap buruk rupa. Perempuan dengan tubuh dan wajah muda, serta berpenampilan menarik selalu terlihat menonjol di lingkungannya.

Kedua, mitos tentang kecantikan pun ditampilkan lewat kostum. Dalam hal ini, kostum yang seharusnya berfungsi sebagai penutup tubuh, digunakan untuk menonjolkan tubuh. Hal ini berarti 
terdapat pergeseran makna kostum, yang berfungsi untuk menampakkan identitas maupun ciri khas karakter melalui kostum yang digunakannya. Identitas dan karakter yang ditampakkan tersebut disajikan dalam pilihan kostum yang menyimbolkan suatu sifat atau identitas tertentu.

Ketiga, mitos kecantikan pun terdapat pula melalui sifat. Misalnya penanaman atas nilai-nilai dari generasi terdahulu yang tertanam hingga dewasa. Hingga akhirnya menjadi kebiasaan dan menimbulkan penandaan tertentu. Dalam hal ini, penanaman nilai-nilai atas kecantikan dari generasi perempuan terdahulu akan melekat hingga dewasa sekaligus menjadi sumber kekuatan khususnya pada perempuan. Mitos kecantikan lainnya adalah kecantikan menjadi alat untuk memperoleh kekuasaan atau kemenangan.

Kisah dongeng merupakan cerita yang diangkat dari kisah-kisah yang berkembang di masyarakat pada zamannya. Dan diceritakan turun temurun dari generasi ke generasi dengan zaman, tahun dan kondisi sosial yang berbeda. Sehingga mitos-mitos yang berkembang pada saat itu juga berbeda.

Begitupun halnya dengan mitos kecantikan, yang selalu mengalami perubahan seiring dengan berkembangnya zaman diikuti dengan kemajuan teknologi. Namun semenjak kemunculan media, khususnya film. Kecantikan pada akhirnya menjadi sama. Kecantikan atau keindahan adalah seperti apa yang ditunjukkan oleh film. Karena efeknya yang begitu besar terutama terhadap pola pikir masyarakat tersebut. Pada akhirnya persepsi kecantikan pada setiap orang menjadi sama.

Mitos kecantikan tersebut pada akhirnya merujuk kepada salah satu ideologi konservatisme. Ideologi ini didasari oleh adanya peraturan untuk menjaga kestabilan yang telah ada. Sesuai dengan mitos kecantikan. Setiap orang selalu ingin mempertahankan kecantikan. Dalam hal ini, kestabilan disimbolkan sebagai kecantikan. 


\section{Daftar Pustaka}

Barthes, Roland. 2011. Mitologi Roland Barthes, (Terj.Nurhadi, A. Sihabul Millah). Bantul: Kreasi Wacana.

Benshoff, M. Harry., Sean Griffin.2009. America on Film: Representing Race, Class,Gender, and Sexuality at The Movies. United Kingdom: A John Wiley \& Sons, Ltd.

Budiman, Kris. 2011. Semiotika Visual: Konsep, Isu, dan Problem Ikonisitas. Yogyakarta: Jalasutra.

Danesi, Marcel. 2010. Pengantar memahami Semiotika Media, Terj. A. Gunawan Admiranto. Yogyakarta: Jalasutra.

Fiske, John. 2011. Cultural and Communication Studies: Sebuah pengantar Paling Komprehensif (Terj. Drs. Yosal Iriantara, MS dan Idi Subandy Ibrahim). Yogyakarta: Jalasutra.
Hall, Stuart. 1997. "Representation” dalam Representation: Cultural Representations and Signifying Practices. Stuart Hall (Ed). London: SAGE Publications Ltd.

Kuper Adam, Jessica Kuper. 2003. The Social Science Encyclopedia. London: Routledge.

Sturken, Marita and Lisa Cartwright. 2009. Practices of Looking: An Introduction to Visual Culture. New York: Oxford University Press, Inc.

Pilliang, Yasraf Amir. 2009. Posrealitas: Realitas Kebudayaan dalam Era Posmetafisika.Yogyakarta:

Jalasutra.

Pilliang, Yasraf Amir. 2012. Semiotika dan Hipersemiotika: Gaya, Kode, dan Matinya Makna. Bandung: MATAHARI.

Wolf, Naomi. 2002. The Beauty Myth: How Images of Beauty Are Used Against Women. New York: Harper Collins e-book. 
Jurnal komunikasi, Volume 8, Nomor 1, Oktober 2013 